\title{
Multifactor Effects on the N2O Emissions and Yield of Potato Fields Based on the DNDC Model
}

\section{Liwei Wang}

Shenyang Agricultural University

\section{Kai Zhang}

Shenyang Agricultural University

\section{Kangjun Guo}

Shenyang Agricultural University

Limin Liu

Shenyang Agricultural University

\section{Tao Zhang}

Shenyang Agricultural University

\section{Mingjie Xu}

Shenyang Agricultural University

\section{Xuefei Yan}

Shenyang Agricultural University

Xining Gao ( $\sim$ syaugxn@syau.edu.cn )

Shenyang Agricultural University https://orcid.org/0000-0002-7166-5814

\section{Research Article}

Keywords: DNDC model, N2O, Potato, Sensitivity test, Emission reducing, Yield

Posted Date: September 13th, 2021

DOI: https://doi.org/10.21203/rs.3.rs-767424/v1

License: (c) (i) This work is licensed under a Creative Commons Attribution 4.0 International License.

Read Full License

Version of Record: A version of this preprint was published at Environmental Science and Pollution Research on November 29th, 2021. See the published version at https://doi.org/10.1007/s11356-02117700-2. 


\title{
Multifactor effects on the $\mathrm{N}_{2} \mathrm{O}$ emissions and yield of potato fields based on the
}

\section{DNDC model}

\author{
Liwei Wang, Kai Zhang, Kangjun Guo, Limin Liu, Tao Zhang, Mingjie Xu, Xuefei Yan, Xining Gao* \\ College of Agronomy, Shenyang Agricultural University, Shenyang 110866, China; \\ wlw@syau.edu.cn (L.W.); zhangkaiheart@163.com (K.Z.); guokangjunSYAU@163.com (K.G.); 1_limin@qq.com \\ (L.L.); zhangt@syau.edu.cn (T.Z.); xumj@ syau.edu.cn (M.X.); syau_yanxuefei@163.com (X.Y.); \\ syaugxn@syau.edu.cn (X.G.) \\ *Correspondence: syaugxn@syau.edu.cn (X.G.)
}

Abstract: Maintaining or increasing grain yields while also reducing the emissions of field agricultural greenhouse gases is an important objective. To explore the multifactor effects of nitrogen fertilizer on nitrous oxide $\left(\mathrm{N}_{2} \mathrm{O}\right)$ emissions and the yield of potato fields and to verify the applicability of the DeNitrification-DeComposition (DNDC) model when used to project the $\mathrm{N}_{2} \mathrm{O}$ emission load and yield, this research chooses a potato field in Shenyang northeast China from 2017 2019 as the experiment site. The experiment includes four nitrogen levels observed the emission of $\mathrm{N}_{2} \mathrm{O}$ by static chamber/gas chromatograph techniques. The results of this study are as follows: (1) DNDC has a good performance regarding the projection of $\mathrm{N}_{2} \mathrm{O}$ emissions and yields. The model efficiency index EFs were $0.45 \sim 0.88$ for $\mathrm{N}_{2} \mathrm{O}$ emissions and $0.91,0.85$ and 0.85 for yields from 2017 2019. (2) The annual precipitation, soil organic carbon and soil bulk density had the most significant influence on the accumulated $\mathrm{N}_{2} \mathrm{O}$ emissions during the growth period of potato. The annual precipitation, annual average temperature and $\mathrm{CO}_{2}$ mass concentration had the most significant influences on yield. (3) Under the premise of a normal water supply, sowing potatoes within 5 days after the 5-day sliding average temperature in this area exceeds $10{ }^{\circ} \mathrm{C}$ can ensure the temperature required for the normal growth of potatoes and achieve the purpose of maintaining and increasing yield. (4) The application of $94.5 \mathrm{~kg} \cdot \mathrm{hm}^{-2}$ nitrogen and $15 \mathrm{~mm}$ irrigation represented the best results for reducing $\mathrm{N}_{2} \mathrm{O}$ emissions while also maintaining the yield in potato fields.

Key words: DNDC model; $\mathrm{N}_{2} \mathrm{O}$; Potato; Sensitivity test; Emission reducing; Yield

\section{Introduction}

The increasing concentration of greenhouse gases in the atmosphere is an important cause of global warming. The fifth report of the IPCC states that anthropogenic greenhouse gas emissions have a direct impact on global warming (Stocker, et al. 2013). $\mathrm{N}_{2} \mathrm{O}$ is a potent greenhouse gas with a 120 year atmospheric lifespan and a global warming potential that is 298 times higher than that of $\mathrm{CO}_{2}$ over a 100 year timescale, and it accounts for approximately $8 \%$ of 
global warming effects (Hu, et al., 2016). More than $59 \%$ of the anthropogenic $\mathrm{N}_{2} \mathrm{O}$ emissions are from agricultural soil (Sanchez-Martín, et al., 2010); therefore, it is necessary to reduce $\mathrm{N}_{2} \mathrm{O}$ emissions from agricultural activities.

Numerous studies have shown that farmland $\mathrm{N}_{2} \mathrm{O}$ emissions are affected by many factors, such as soil temperature, moisture, and fertilization levels (Barton, et al., 2008; Elmi, et al., 2009). Agehara et al. (2005) showed that the soil $\mathrm{N}_{2} \mathrm{O}$ emission flux increased along with temperature to a certain soil temperature and usually reached the maximum within the range of $25 \sim 35{ }^{\circ} \mathrm{C}$. Soil moisture can affect $\mathrm{N}_{2} \mathrm{O}$ emissions by influencing the soil microbial activity, soil REDOX potential and soil aeration (Luo, et al., 2013), and it is generally expressed by the soil water filled pore space (WFPS) in studies of soil moisture content. The relationship between $\mathrm{N}_{2} \mathrm{O}$ emission and soil moisture content is parabolic, with $\mathrm{N}_{2} \mathrm{O}$ emissions increasing with increasing soil moisture content when the WFPS is less than $75 \%$ but decreasing when the WFPS is more than 75\% (Kallenbach, et al., 2010). The application of nitrogen fertilizer is the most direct source of nitrogen in farmland soil and has a significant effect on the $\mathrm{N}_{2} \mathrm{O}$ emissions from farmland soil. Many researchers have observed and verified that soil $\mathrm{N} 2 \mathrm{O}$ emissions increase rapidly with the increase of nitrogen application (Burton, et al., 2008; Zebarth, et al., 2012). Field observations cannot accurately reflect the impact of different management measures on $\mathrm{N}_{2} \mathrm{O}$ emissions in farmland due to the high variability of soil $\mathrm{N}_{2} \mathrm{O}$ emissions in time and space and the complex relationship between climate and soil (Shang, et al., 2011). Therefore, the emission law of farmland $\mathrm{N}_{2} \mathrm{O}$ and its emission reduction potential must be evaluated based on models (Robertson, et al., 2004; Khalil, et al., 2020).

The DeNitrification-DeComposition (DNDC) model is a computer simulation model that describes the biogeochemical processes of carbon and nitrogen in agricultural ecosystems ( $\mathrm{Li}$, et al., 1992), and it can be used to simulate the emissions of carbon, nitrogen and other gases in agricultural ecosystems as well as the crop yield, soil carbon sequestration and nitrate leaching, etc. (Giltrap, et al., 2010). The DNDC model is one of the most successful biogeochemical models in the world. Many researchers have independently verified the DNDC model with their own data, indicating that the DNDC model has a good simulation effect on agricultural greenhouse gas emissions, crop yields and other parameters (Li, et al., 2012; Han, et al., 2014). Many studies have shown that $\mathrm{N}_{2} \mathrm{O}$ emissions can be affected significantly by environmental factors and farming management by DNDC (Shah, et al., 2020; Deng, et al., 2020). So we can use DNDC for reducing the need for replicated field experiments.

Previous studies on the driving factors underlying farmland $\mathrm{N}_{2} \mathrm{O}$ emissions mainly focused on using models to explore grain crops, such as wheat (Triticum aestivum L.), maize (Zea mays L.) and rice (Oryza sativa) (Tumer, et al., 2015). However, little research has been done on field studies of $\mathrm{N}_{2} \mathrm{O}$ and DNDC simulations in potato(Solanum tuberosum) crop systems (Zhang and Niu, 2016). Because potato is one of the most important crops, it is becoming 
increasingly important to explore the driving factors for the $\mathrm{N}_{2} \mathrm{O}$ emissions and yield in potato fields, especially because of the continuous increase of potato planting area in China (Zhang, et al., 2014). We used the DNDC model to study the $\mathrm{N}_{2} \mathrm{O}$ emissions and yield driving factors and provided a scientific basis for the formulation of $\mathrm{N}_{2} \mathrm{O}$ emission reduction and yield promotion measures in potato fields.

2. Materials and methods

\subsection{Study site}

This study was conducted from 2017 2019 at the Shenyang Agricultural University Experimental Base $\left(41^{\circ} 49^{\prime} \mathrm{N}\right.$, $\left.123^{\circ} 33^{\prime} \mathrm{E}\right)$ in Shenyang, Liaoning Province, Northeast China. The base is located in a warm temperate sub-humid continental monsoon climate region. The annual average temperature is $8.0^{\circ} \mathrm{C}$, and the average annual precipitation is $716.2 \mathrm{~mm}$ ( $80 \%$ of which occurs from June to September). The frost-free period is approximately $145 \sim 163$ days each year. The soil type is silty loam (clay $=15 \%$, loam $=51 \%$, and sand $=34 \%$ ), the soil bulk density is $1.297 \mathrm{~g} \cdot \mathrm{cm}^{-3}$, and the $\mathrm{pH}$ is 6.42 on average in $0 \sim 20 \mathrm{~cm}$ depth of the soil, respectively.

\subsection{Experimental design}

The potato-growing period lasted 88 days in 2017 (from April 28 to July 24), 88 days in 2018 (from April 30 to July 26), and 90 days in 2019 (from April 26 to July 24). The experiment consisted of four different amounts of nitrogen fertilizer (urea) and four treatments in one field: no $\mathrm{N}$ fertilizer (N0) $\left(0 \mathrm{kgN} \cdot \mathrm{hm}^{-2}\right)$, low fertilizer (N1) $\left(60 \mathrm{kgN} \cdot \mathrm{hm}^{-2}\right)$, middle fertilizer (N2) $\left(120 \mathrm{kgN} \cdot \mathrm{hm}^{-2}\right)$, and high fertilizer $(\mathrm{N} 3)\left(180 \mathrm{kgN} \cdot \mathrm{hm}^{-2}\right)$. All the treatments were organized in a randomized block design with three replicates (each treatment area was $5 \mathrm{~m} \times 6 \mathrm{~m}$ ). Potato planting row spacing was $0.5 \mathrm{~m}$, and plant spacing was $0.4 \mathrm{~m}$. Potatoes were planted by ridge planting with a ridge width of $0.5 \mathrm{~m}$, a ridge height of $0.15 \mathrm{~m}$, and a ditch width of $0.5 \mathrm{~m}$. Phosphatic fertilizer $\left(\mathrm{P}_{2} \mathrm{O}_{5}\right)$ was applied at $225 \mathrm{~kg} \cdot \mathrm{hm}^{-2}$, and potassic fertilizer $\left(\mathrm{K}_{2} \mathrm{O}\right)$ was applied at $75 \mathrm{~kg} \cdot \mathrm{hm}^{-2}$. The fertilization method included a one-time base fertilizer application before sowing 1 day. The tillage method included plowing to $20 \mathrm{~cm}$ before sowing 5 days. No artificial irrigation was performed (rain-fed). Regular artificial weeding (pulling weeds by hand) was performed. The potato cultivar was You Jin, which is an early-maturing variety with a growth period of approximately 90 days. It is currently planted in large areas in Liaoning Province.

\subsection{Method of analyzing the samples}

$\mathrm{N}_{2} \mathrm{O}$ emission fluxes were observed using the static chamber-gas chromatography method and manual sampling (Mapanda et al., 2011). The static chamber size was $60 \mathrm{~mm} \times 50 \mathrm{~mm} \times 45 \mathrm{~mm}$. The static chambers were set on ridges included plants within the chamber in the middle of each experimental plot after basal fertilizer and before sowing. Gas samples were measured daily five days after fertilization and then once a week at other times. If rain occurred, gas 
samples would be measured 1 more time after the rain day. When the $\mathrm{N}_{2} \mathrm{O}$ emission fluxes were measured, the soil moisture (by the oven-drying method), air temperature (by thermometer) and soil temperature (by soil thermometer) at 0, 10 and $20 \mathrm{~cm}$ were synchronously measured. Each sampling time was at 09:00-11:00, and the gas sample amount was $80-100 \mathrm{ml}$ and extracted using an air pump. Gas samples were analyzed using an Agilent 7890A gas chromatograph (Agilent Technologies, USA), and the daily $\mathrm{N}_{2} \mathrm{O}$ emission fluxes were calculated using a linear regression analysis according to the following equation:

$$
\text { Flux }=\rho \times V \times \Delta C \times 273 / A \times \Delta t \times(273+T)
$$

where flux is the gas exchange flux of $\mathrm{N}_{2} \mathrm{O}\left(\mu \mathrm{g} \mathrm{m}^{-2} \mathrm{~h}^{-1}\right), \rho$ is the gas density $\left(\mathrm{mg} \mathrm{m}^{-2}\right), V$ is volume of the static chamber box $\left(\mathrm{m}^{3}\right), A$ is the bottom area of the box $\left(\mathrm{m}^{2}\right), \Delta C$ is the gas concentration difference, $\Delta t$ is the time interval (h), and $T$ is the temperature $\left({ }^{\circ} \mathrm{C}\right)$. A negative gas exchange flux means that the observed system absorbs gas from the atmosphere, while a positive flux means the system is discharging gas into the atmosphere.

\subsection{DNDC Model}

\subsubsection{Initial conditions}

The DNDC model is version 9.5, and it consists of two parts: the climate, crop growth, and soil conditions that convert main drivers (e.g., climate, soil properties, vegetation, and anthropogenic activity) to soil environmental factors (e.g., temperature, moisture, $\mathrm{pH}$, redox potential, and substrate concentration gradients) and the nitrification, denitrification, and fermentation submodels that simulate $\mathrm{C}$ and $\mathrm{N}$ transformations mediated by the soil microbial activities (Deng, et al., 2011). To correct the model, some parameters that are not consistent with the actual field growth in the local area are modified so that the actual model parameters in the applied area are determined. The input parameters were as follows: latitude and longitude $\left(41^{\circ} 49^{\prime} \mathrm{N}\right.$ and $\left.123^{\circ} 33^{\prime} \mathrm{E}\right)$; maximum daily temperature $\left({ }^{\circ} \mathrm{C}\right)$, minimum daily temperature $\left({ }^{\circ} \mathrm{C}\right)$, daily precipitation $(\mathrm{mm})$, daily mean wind speed $\left(\mathrm{m} \cdot \mathrm{s}^{-1}\right)$, and relative humidity $(\%)$, which were provided by the Shenyang Meteorological Bureau; soil type (silty loam); pH (6.42); field capacity (0.25 $\left.\mathrm{g} \cdot \mathrm{g}^{-1}\right)$; soil bulk density $\left(1.297 \mathrm{~g} \cdot \mathrm{cm}^{-3}\right)$; organic matter content of the topsoil $(0 \sim 10 \mathrm{~cm})\left(12.48 \mathrm{~g} \cdot \mathrm{kg}^{-1}\right)$; average mass concentration of $\mathrm{N}$ in precipitation $\left(3.26 \mathrm{mg} \cdot \mathrm{L}^{-1}\right)$; and average concentration of $\mathrm{CO}_{2}$ in the atmosphere $\left(400 \mathrm{mg} \cdot \mathrm{m}^{-3}\right)$, which were determined according to local actual production conditions, test sample analyses as well as relevant literature (Raymundo, et al., 2017). The adjusted potato-related parameters were as follows: optimum potato yield $\left(25000 \mathrm{~kg} \cdot \mathrm{hm}^{-2}\right)$; potato growth cumulative temperature $\left(1300^{\circ} \mathrm{C}\right)$; potato biomass allocation ratio (Grain: Leaf: Stem: Root was 0.60:0.20:0.18:0.02); and water requirement (400 $\mathrm{kg} \cdot \mathrm{kg}^{-1}$ dry matter).

\subsubsection{Model test method}

Three statistical indexes, the coefficient of determination $\left(R^{2}\right)$, average error $(E)$ and model efficiency index $(E F)$, 
were used for the quantitative comparisons.

$$
\begin{aligned}
& R^{2}=\left(\frac{\sum_{i=1}^{n}\left(S_{i}-\overline{S_{i}}\right)\left(M_{i}-\overline{M_{i}}\right)}{\sqrt{\sum_{i=1}^{n}\left(S_{i}-\overline{S_{i}}\right)^{2} \sum_{i=1}^{n}\left(M_{i}-\overline{M_{i}}\right)^{2}}}\right)^{2} \\
& E=\frac{\sum_{i=1}^{n}\left(S_{i}-M_{i}\right)}{n}
\end{aligned}
$$

$$
E F=1-\frac{\sum_{i=1}^{n}\left(S_{i}-M_{i}\right)^{2}}{\sum_{i=1}^{n}\left(S_{i}-\bar{M}\right)^{2}}
$$

where $S_{i}$ and $M_{i}$ are the simulated and observed values, respectively; $\bar{M}_{i}$ and $\overline{S_{i}}$ are their averages, respectively; and $n$ is the number of observations. The closer $\mathrm{R}^{2}$ is to 1 , the better the model fits. The average error $\mathrm{E}$ represents the average of the error between the observed value and the simulated value. The larger the absolute value of E, the larger the average error. When the average error $\mathrm{E}$ is $>0$, the observed value is less than the simulated value, and when $\mathrm{E}$ is $<0$, the observed value is greater. When $\mathrm{EF}$ is $0 \sim 1$, it is the larger the value, the greater the correlation between the observed value and the simulated value. When $\mathrm{EF}$ is $<0$, the observed value is extremely uncorrelated with the simulated value (Yang, et al., 2014).

\begin{tabular}{|c|c|c|c|}
\hline Factors & Parameters & Baseline & Alternative range \\
\hline & Annual precipitation $/ \mathrm{mm}$ & 716.2 & $859.4,787.8,716.2,644.6,573.0$ \\
\hline Meteorological & Annual average temperature $/{ }^{\circ} \mathrm{C}$ & 8.0 & $10.0,9.0,8.0,7.0,8.0$ \\
\hline \multirow[t]{3}{*}{ factors } & $\mathrm{CO}_{2}$ mass concentration $/\left(\mathrm{mg} \cdot \mathrm{m}^{-3}\right)$ & 400 & $440,420,400,380,360$ \\
\hline & Nitrogen deposition (by $\mathrm{N}) /\left(\mathrm{mg} \cdot \mathrm{L}^{-1}\right)$ & 3.26 & $3.912,3.586,3.912,3.26,2.934,2.608$ \\
\hline & Soil organic carbon $/\left(\mathrm{g} \cdot \mathrm{g}^{-1}\right)$ & 0.01248 & $0.01498,0.01373,0.01248,0.01123,0.00998$ \\
\hline \multirow[t]{2}{*}{ Soil factors } & Soil pH & 6.42 & $5.136,5.778,6.42,7.062,7.704$ \\
\hline & Soil capacity $/\left(\mathrm{g} \cdot \mathrm{cm}^{-3}\right)$ & 1.297 & $1.556,1.427,1.297,1.167,1.038$ \\
\hline $\begin{array}{c}\text { Field } \\
\text { management }\end{array}$ & Nitrogen application/(kg. hm-2) & 120 & $240,180,120,60,0$ \\
\hline
\end{tabular}

2.4.3 Sensitivity analysis method

Table 1 Background values and test values of the sensitivity test indexes. 
factor

In the sensitivity analysis, the numerical input of one of the influencing factors in the DNDC model is changed within a certain range while keeping the other influencing factors unchanged to obtain the change law of the output value. Multi-year averages and actual local production conditions were selected as the baseline data. Different impact factors were set to simulate the $\mathrm{N}_{2} \mathrm{O}$ emissions and yield from the potato field (Table 1). The sensitivity index $\mathrm{S}$ (Walker, et al., 2000) was used to study the effect of these factors on the yield of potato field $\mathrm{N}_{2} \mathrm{O}$ emissions. The calculation formula of $\mathrm{S}$ was as follows:

$$
S=\left(\left(O_{2}-O_{1}\right) / O_{a v g}\right) /\left(\left(I_{2}-I_{1}\right) / I_{a v g}\right)
$$

where $S$ is sensitivity index; $I_{1}$ and $I_{2}$ are the minimum and maximum values of the input parameters, respectively; $O_{1}$ and $O_{2}$ are the minimum and maximum values of the output parameters, respectively; $I_{a v g}$ is the average of the input parameters; and $O_{\text {avg }}$ is the average of the output parameters. The larger the absolute value of S, the greater the influence of the input parameters on the output and the stronger the correlation between them. $\mathrm{S}>0$ indicates a positive correlation between the input parameter and the output, and $\mathrm{S}<0$ indicates a negative correlation.

SPSS 17.0 and Excel 2010 software were used for the analysis of variance (ANOVA) and linear regression analysis in this study. The meteorological data required for the test were provided by the Shenyang Meteorological

Bureau.

3. Results

\subsection{Ancillary data}

The daily average temperatures in the growing periods of 2017,2018 and 2019 were $20.2{ }^{\circ} \mathrm{C}, 19.9^{\circ} \mathrm{C}$ and $19.4{ }^{\circ} \mathrm{C}$, respectively, and the amount of precipitation in the growing periods was $222.4 \mathrm{~mm}, 212.0 \mathrm{~mm}$ and $286.7 \mathrm{~mm}$, respectively (Fig. 1).

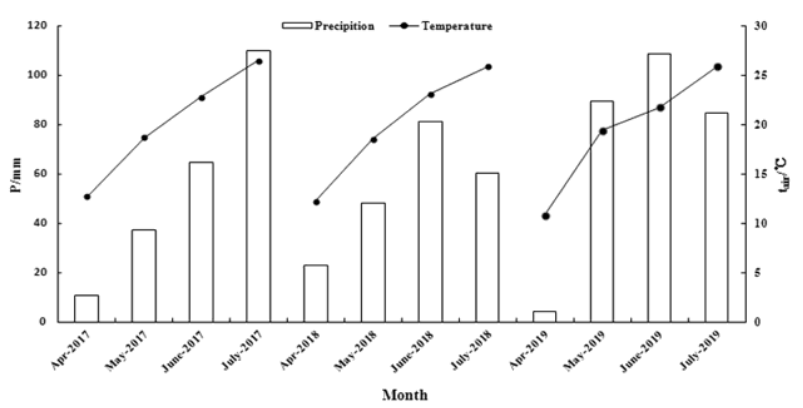

Fig. 1 Monthly average air temperature $\left(t_{\text {air }}\right)$ and monthly precipitation $(P)$ in the experiment field during the experiment 
$3.2 \mathrm{~N}_{2} \mathrm{O}$ emission flux and yield with different nitrogen levels in the potato field

As shown in Fig. 2, the emission flux of the N3 treatment was significantly higher than that of other treatments, and the emission of $\mathrm{CK}$ was the lowest. The average $\mathrm{N}_{2} \mathrm{O}$ emission rates of the $\mathrm{CK}, \mathrm{N} 0, \mathrm{~N} 1, \mathrm{~N} 2$, and $\mathrm{N} 3$ treatments were $4.75 \mu \mathrm{g} \cdot \mathrm{m}^{-2} \cdot \mathrm{h}^{-1}, 9.97 \mu \mathrm{g} \cdot \mathrm{m}^{-2} \cdot \mathrm{h}^{-1}, 21.99 \mu \mathrm{g} \cdot \mathrm{m}^{-2} \cdot \mathrm{h}^{-1}, 45.83 \mu \mathrm{g} \cdot \mathrm{m}^{-2} \cdot \mathrm{h}^{-1}$ and $77.05 \mu \mathrm{g} \cdot \mathrm{m}^{-2} \cdot \mathrm{h}^{-1}$ in 2017 , respectively; $6.39 \mu \mathrm{g} \cdot \mathrm{m}^{-2} \cdot \mathrm{h}^{-1}, 7.70 \mu \mathrm{g} \cdot \mathrm{m}^{-2} \cdot \mathrm{h}^{-1}, 10.48 \mu \mathrm{g} \cdot \mathrm{m}^{-2} \cdot \mathrm{h}^{-1}, 21.29 \mu \mathrm{g} \cdot \mathrm{m}^{-2} \cdot \mathrm{h}^{-1}$ and $35.27 \mu \mathrm{g} \cdot \mathrm{m}^{-2} \cdot \mathrm{h}^{-1}$ in 2018 , respectively; and $10.92 \mu \mathrm{g} \cdot \mathrm{m}^{-2} \cdot \mathrm{h}^{-1}, 11.83 \mu \mathrm{g} \cdot \mathrm{m}^{-2} \cdot \mathrm{h}^{-1}, 19.43 \mu \mathrm{g} \cdot \mathrm{m}^{-2} \cdot \mathrm{h}^{-1}, 25.45 \mu \mathrm{g} \cdot \mathrm{m}^{-2} \cdot \mathrm{h}^{-1}$ and $39.72 \mu \mathrm{g} \cdot \mathrm{m}^{-2} \cdot \mathrm{h}^{-1}$ in 2019 , respectively. The $\mathrm{N}_{2} \mathrm{O}$ emission flux of soil showed a significant increasing trend as the nitrogen application rate increased. The trends and fluctuations of $\mathrm{N}_{2} \mathrm{O}$ emissions in all treatments were basically consistent, which indicated that nitrogen application would not lead to the changes in the emission trend but only affected the amount of soil $\mathrm{N}_{2} \mathrm{O}$ emissions.
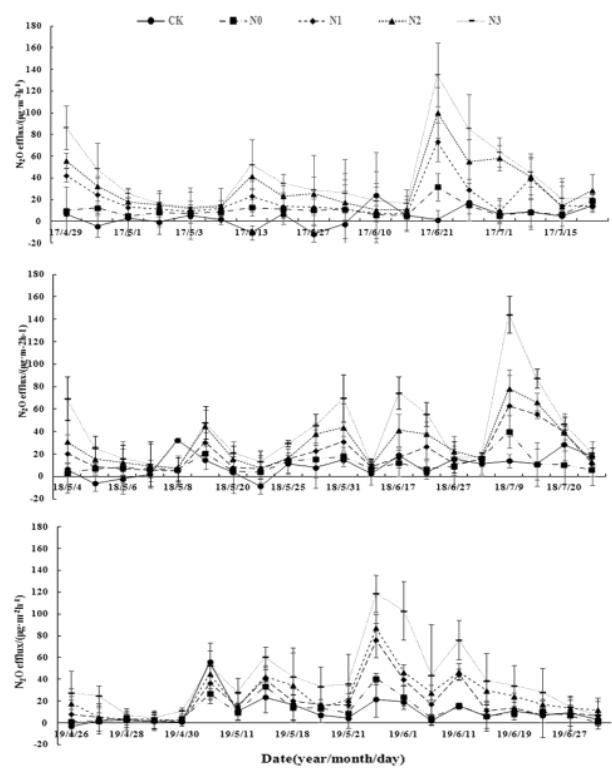

Fig. $2 \mathrm{~N}_{2} \mathrm{O}$ emissions from the potato field under different nitrogen application levels from 2017 to 2019

As shown in Fig. 3, the potato yield of different treatments showed basically the same rule in three years. That is, the treatment without nitrogen fertilizer was significantly lower than that of other treatments. Moreover, it was found that the yield did not increase continuously with the increase of nitrogen application rate. Excessive application of nitrogen fertilizer would decrease the yield to some extent.

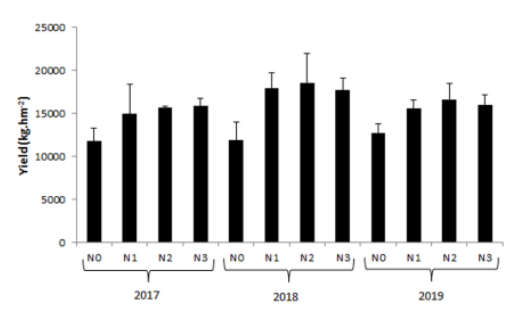

Fig. 3 Yield of potato from 2017 to 2019

3.3 DNDC model calibration and validation 
Table 2 Fitting indexes of $\mathrm{N}_{2} \mathrm{O}$ emissions and yield for the DNDC model

\begin{tabular}{|c|c|c|c|c|c|}
\hline Year & Treatment & $R^{2}$ & $P$ & $E$ & $\mathrm{EF}$ \\
\hline \multirow{5}{*}{2017} & No & 0.92 & 0.000 & -1.17 & 0.88 \\
\hline & N1 & 0.88 & 0.000 & 4.90 & 0.85 \\
\hline & $\mathrm{N} 2$ & 0.74 & 0.000 & 1.98 & 0.73 \\
\hline & N3 & 0.62 & 0.000 & -19.79 & 0.45 \\
\hline & Yield $/\left(\mathrm{kg} \cdot \mathrm{hm}^{-2}\right)$ & 0.97 & 0.017 & -403.82 & 0.91 \\
\hline \multirow{5}{*}{2018} & No & 0.87 & 0.000 & -0.89 & 0.80 \\
\hline & N1 & 0.84 & 0.000 & 6.31 & 0.63 \\
\hline & $\mathrm{N} 2$ & 0.87 & 0.000 & 6.35 & 0.64 \\
\hline & N3 & 0.90 & 0.000 & -0.78 & 0.83 \\
\hline & Yield $/\left(\mathrm{kg} \cdot \mathrm{hm}^{-2}\right)$ & 0.95 & 0.027 & 761.58 & 0.85 \\
\hline \multirow{5}{*}{2019} & No & 0.76 & 0.000 & 5.43 & 0.58 \\
\hline & $\mathrm{N} 1$ & 0.88 & 0.000 & 9.36 & 0.63 \\
\hline & $\mathrm{N} 2$ & 0.83 & 0.000 & 11.24 & 0.56 \\
\hline & $\mathrm{N} 3$ & 0.81 & 0.000 & 4.37 & 0.66 \\
\hline & Yield/ $\left(\mathrm{kg} \cdot \mathrm{hm}^{-2}\right)$ & 0.92 & 0.040 & 52.29 & 0.85 \\
\hline
\end{tabular}

Note: the number of $\mathrm{N}_{2} \mathrm{O}$ emissions and yield observations were 18 and 4 in 2017, 20 and 4 in 2018, 20 and 4 in 2019 , respectively.

The data in 2017 and 2018 were used for DNDC model tuning, and the data in 2019 were used for DNDC model validation. In general, the simulation of the $\mathrm{N}_{2} \mathrm{O}$ emission effect for the low nitrogen treatment was better than that of the high nitrogen treatment in Table.2. The average efficiency index EF of the $\mathrm{N}_{2} \mathrm{O}$ emissions and yield simulation models were $0.69(P<0.01)$ and $0.87(P<0.01)$ in 2017 2019, which indicated that DNDC model had a good simulation effect on both the $\mathrm{N}_{2} \mathrm{O}$ emissions and yield of the potato field as shown in Fig. 4.
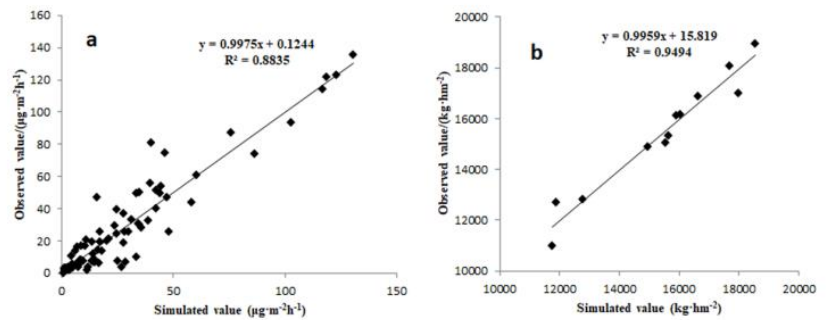

Fig. 4 Comparison of simulated and observed values about $\mathrm{N}_{2} \mathrm{O}$ emissions (a) and yield (b) 


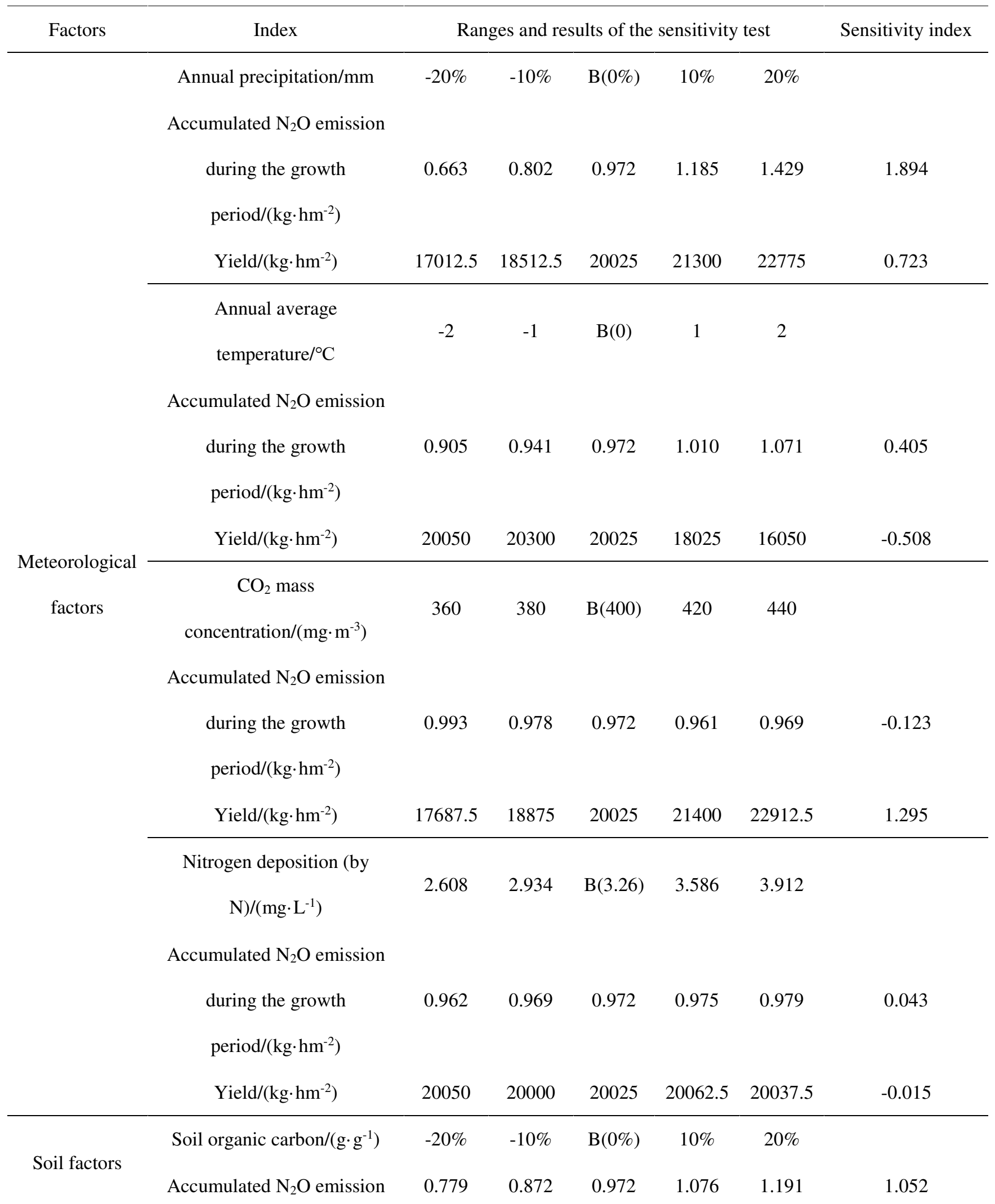


during the growth

period $/\left(\mathrm{kg} \cdot \mathrm{hm}^{-2}\right)$

\begin{tabular}{ccccccc} 
Yield $/\left(\mathrm{kg} \cdot \mathrm{hm}^{-2}\right)$ & 20075 & 20025 & 20025 & 20037.5 & 20062.5 & -0.002 \\
\hline soil pH & $-20 \%$ & $-10 \%$ & $\mathrm{~B}(0 \%)$ & $10 \%$ & $20 \%$ &
\end{tabular}

Accumulated $\mathrm{N}_{2} \mathrm{O}$ emission

$\begin{array}{lllllll}\text { during the growth } & 0.717 & 0.875 & 0.972 & 0.844 & 0.614 & 0.319\end{array}$

$\operatorname{period} /\left(\mathrm{kg} \cdot \mathrm{hm}^{-2}\right)$

\begin{tabular}{ccccccc} 
Yield $/\left(\mathrm{kg} \cdot \mathrm{hm}^{-2}\right)$ & 20012.5 & 20062.5 & 20025 & 20000 & 19950 & -0.008 \\
\hline Soil capacity $/\left(\mathrm{g} \cdot \mathrm{cm}^{-3}\right)$ & $-20 \%$ & $-10 \%$ & $\mathrm{~B}(0 \%)$ & $10 \%$ & $20 \%$ &
\end{tabular}

Accumulated $\mathrm{N}_{2} \mathrm{O}$ emission

$\begin{array}{lllllll}\text { during the growth } & 0.773 & 0.866 & 0.972 & 1.080 & 1.216 & 1.129\end{array}$

$\operatorname{period} /\left(\mathrm{kg} \cdot \mathrm{hm}^{-2}\right)$

$\begin{array}{lllllll}\text { Yield } /\left(\mathrm{kg} \cdot \mathrm{hm}^{-2}\right) & 20000 & 20025 & 20025 & 19950 & 20025 & 0.003\end{array}$

\begin{tabular}{|c|c|c|c|c|c|c|c|}
\hline \multirow{3}{*}{$\begin{array}{c}\text { Field } \\
\text { management } \\
\text { factors }\end{array}$} & $\begin{array}{c}\text { Nitrogen } \\
\text { applications } /\left(\mathrm{kg} \cdot \mathrm{hm}^{-2}\right)\end{array}$ & 0 & 60 & $\mathrm{~B}(120)$ & 180 & 240 & \\
\hline & $\begin{array}{l}\text { Accumulated } \mathrm{N}_{2} \mathrm{O} \text { emission } \\
\text { during the growth } \\
\text { period } /\left(\mathrm{kg} \cdot \mathrm{hm}^{-2}\right)\end{array}$ & 0.214 & 0.771 & 0.972 & 1.144 & 1.315 & 0.624 \\
\hline & Yield $/\left(\mathrm{kg} \cdot \mathrm{hm}^{-2}\right)$ & 17012.5 & 20025 & 20025 & 20000 & 19937.5 & 0.045 \\
\hline
\end{tabular}

Note: B means the baseline in Table 1.

The sensitivity testing identified changes in the different driving factors (Table 3), and the following results were obtained.

Meteorological factors. (1) The cumulative $\mathrm{N}_{2} \mathrm{O}$ emissions and yield of the potato field during the growth period showed an increasing trend with the increase of annual precipitation. The cumulative $\mathrm{N}_{2} \mathrm{O}$ emissions and yield during the growing period of the potato field increased by $21.2 \%$ and $7.6 \%$ on average for every $10 \%$ increase in annual precipitation, respectively. The sensitivity indexes were 1.894 and 0.723 , which indicated high sensitivity. (2) The cumulative $\mathrm{N}_{2} \mathrm{O}$ emissions increased with the increase of average annual temperature during the growth period in the potato field by $4.3 \%$ on average for every $1{ }^{\circ} \mathrm{C}$ increase in annual temperature. The sensitivity index was 0.405 . However, the yield decreased with the increase of annual temperature under the management of potato field in this 
region by an average of $5.3 \%$ for every $1{ }^{\circ} \mathrm{C}$ increase in annual temperature. The sensitivity index was -0.508 . (3) The cumulative change of $\mathrm{N}_{2} \mathrm{O}$ emissions during the growing period of the potato field was small with the change of the atmospheric $\mathrm{CO}_{2}$ mass concentration in the range of $360 \sim 440 \mathrm{mg} \cdot \mathrm{m}^{-3}$ and decreased by an average of $0.6 \%$ for every 20 $\mathrm{mg} \cdot \mathrm{m}^{-3}$ increase in $\mathrm{CO}_{2}$ mass concentration in the atmosphere. The sensitivity index was only -0.123 . With the increase of $\mathrm{CO}_{2}$ concentration in the atmosphere, the potato yield increased by an average of $6.7 \%$ for every $20 \mathrm{mg} \cdot \mathrm{m}^{-3} \mathrm{increase}$ in $\mathrm{CO}_{2}$ mass concentration in the atmosphere. The sensitivity index was 1.295 . (4) The cumulative change of $\mathrm{N}_{2} \mathrm{O}$ emissions during the growing period of the potato field was small with the change of nitrogen deposition in the range of $2.608 \sim 3.912 \mathrm{mg} \cdot \mathrm{L}^{-1}$. The cumulative $\mathrm{N}_{2} \mathrm{O}$ emissions and yield during the growing period of potato field increase by only by $0.4 \%$ and $0.02 \%$ on average for every $10 \%$ change of nitrogen deposition, and the sensitivity indexes were only 0.043 and -0.015 , respectively.

Soil factors. (1) The cumulative $\mathrm{N}_{2} \mathrm{O}$ emissions in the potato field during the growth period showed a significant increasing trend as the soil organic carbon (SOC) content increased. The emission increased by $11.2 \%$ on average for every $10 \%$ of SOC, and the sensitivity index was 1.052 . However, as the organic carbon content in the soil gradually increased between 0.00998 and $0.01498 \mathrm{~g} \cdot \mathrm{g}^{-1}$, the potato yield remained almost unchanged, and the sensitivity index was only -0.002 . (2) The cumulative $\mathrm{N}_{2} \mathrm{O}$ emissions and yield in the potato field showed an obvious trend of initially increasing and then decreasing with the increase of soil $\mathrm{pH}$ during the growth period. The highest cumulative $\mathrm{N}_{2} \mathrm{O}$ emissions and yields were in neutral soil, and they decreased in acidic and alkaline soils, and the sensitivity indexes were 0.319 and -0.008 . (3) Soil bulk density was positively correlated with the cumulative $\mathrm{N}_{2} \mathrm{O}$ emissions in the potato field during the growth period. The cumulative $\mathrm{N}_{2} \mathrm{O}$ emission increased by $12.1 \%$ on average for every $10 \%$ of soil bulk density, and the sensitivity index was 1.129 . The change of yield was small with the change of soil bulk density in the range of $1.038 \sim 1.556 \mathrm{~g} \cdot \mathrm{cm}^{-3}$, and the sensitivity index was only 0.003 .

Field management factors. The nitrogen application rate was positively correlated with the cumulative $\mathrm{N}_{2} \mathrm{O}$ emissions in the potato field during the growth period. The cumulative $\mathrm{N}_{2} \mathrm{O}$ emissions increased by $79.7 \%$ on average for every $60 \mathrm{~kg} \cdot \mathrm{hm}^{-2}$ nitrogen application, and the sensitivity index was 0.624 . The results showed that nitrogen application significantly promoted $\mathrm{N}_{2} \mathrm{O}$ emissions in the potato field and the nitrogen application rate and potato yield showed a parabolic trend. The yield increased as the nitrogen application increased from low nitrogen levels, whereas excessive nitrogen application tended to reduce the yield. The sensitivity index was 0.045 .

\section{Discussion}

4.1 Effects of meteorological factors, soil factors and field management factors on the cumulative $\mathrm{N}_{2} \mathrm{O}$ emissions and yield in the potato field 
Meteorological factors. (1) Precipitation could significantly affect the dynamic changes of soil moisture, change the soil moisture content, and then affect the $\mathrm{N}_{2} \mathrm{O}$ emissions and yields. The $\mathrm{N}_{2} \mathrm{O}$ emissions and yield of the potato field were very sensitive to the soil water content in this study, which has been verified by many research studies (Reyes-Cabrera, et al., 2016; Banerjee, et al., 2016). (2) Air temperature affected the soil $\mathrm{N}_{2} \mathrm{O}$ emissions and yields by affecting the soil temperature. The soil microbial activity and $\mathrm{N}_{2} \mathrm{O}$ emission rate during denitrification and nitrification increased as the soil temperature increased in a certain range. Therefore, the soil $\mathrm{N}_{2} \mathrm{O}$ emission flux is usually positively correlated with soil temperature (Xu, et al., 2017). There was a negative correlation between potato yield and average annual temperature in this region in this study because potato prefers cooler temperatures (Pulatov, et al., 2015). The late sowing of potatoes in this experiment provided a basis for us to explore the early sowing date of potatoes in this region (In section 4.3). (3) The cumulative change of $\mathrm{N}_{2} \mathrm{O}$ emissions during the growing period of potato was small with changes in the atmospheric $\mathrm{CO}_{2}$ mass concentration in this study, which was similar to the results of other studies (Dijkstra, et al., 2012; Lam, et al., 2012). As the basic raw material of photosynthesis, the increase of $\mathrm{CO}_{2}$ concentrations in the atmosphere can affect the photosynthesis of $\mathrm{C} 3$ plants and potatoes in two aspects: competition for the Rubisco binding sites to increase the rate of carboxylation and increasing the photosynthesis reaction substrate by inhibiting photorespiration, thereby increasing the net photosynthetic rate (McGrath and Lobell, 2013). The photosynthetic capacity of $\mathrm{C} 3$ plants can increase by $10 \%$ to $15 \%$ with the increase of $\mathrm{CO}_{2}$ concentrations, thereby increasing the yield (Kou, et al., 2008). (4) The ecological effect of nitrogen deposition in the atmosphere has attracted increasing attention in recent years. Nitrogen input through atmospheric deposition can increase the primary productivity and biomass of nitrogen-deficient ecosystems (Matson, et al., 2002). However, nitrogen inputs do not play a significant nutritional role in nitrogen-saturated ecosystems (Magill, et al., 2000). The baseline scenario in this study is nitrogen-saturated for the potato field ecosystem, and the nitrogen that enters the soil via nitrogen deposition is very small compared to the nitrogen content of the potato field ecosystem. Therefore, the cumulative $\mathrm{N}_{2} \mathrm{O}$ emissions and yields of the potato field were not significantly changed with nitrogen deposition during the growing period.

Soil factors. (1) Soils with higher organic carbon contained more dissolved organic carbon (DOC), which increases substrates for soil nitrification and denitrification and enhances nitrification and denitrification, which in turn increased soil $\mathrm{N}_{2} \mathrm{O}$ emissions ( $\mathrm{Li}$, et al., 2010). The results showed that the potato yield barely changed as the soil organic carbon content increased, which was possibly due to stress from the water supply. (2) Soil $\mathrm{pH}$ affects nitrification and denitrification by affecting the activity of nitrification and denitrification bacteria and changing the rate of nitrification and denitrification and the final product ratio. The highest $\mathrm{N}_{2} \mathrm{O}$ emissions were in neutral soil and they decreased under 
soil $\mathrm{pH}$ and can grow normally when planted with soil $\mathrm{pH}$ between 5 and 7.5 (Agbede, 2010). In this study, the $\mathrm{pH}$ value was basically within this range; therefore, the change of $\mathrm{pH}$ value had no significant effect on the potato yield. (3) Bulk density is an important physical property of soil that can reflect the porosity, tightness and fertility of soil. Soil bulk density affects soil $\mathrm{N}_{2} \mathrm{O}$ emission fluxes by affecting the soil permeability and water diffusion rate. The bulk density reflects the degree of soil compactness. Under the condition of a similar soil texture, a decrease of bulk density indicates that the soil compactness is low and there are more aeration pores. However, under the condition of a constant soil moisture content, the diffusion rate of soil moisture decreases as the soil bulk density increases (Logsdon, et al., 2004). Decreased soil bulk density increases the soil aeration and oxygen content, thereby reducing the number of anaerobic bacteria, which inhibits denitrification and reduces $\mathrm{N}_{2} \mathrm{O}$ emissions (Cavigelli, et al., 2001; Balaine, et al., 2016).

In reality, the influence effectiveness of different factors are very different, such as soil moisture and temperature can directly change the microbial activity and the diffusion rate of soil gas into the atmosphere, and then thus affecting the emissions of $\mathrm{N}_{2} \mathrm{O}$ (Lan, et al., 2018; Cui and Wang, et al., 2019). This part is planned to be combined with experimental data and models to carry out a deeper discussion in the future research.

Field management factors. The application of nitrogen fertilizer has an obvious effect on $\mathrm{N} 2 \mathrm{O}$ emissions as the most direct nitrogen source. The excessive use of nitrogen fertilization was the primary reasons for the increase in $\mathrm{N}_{2} \mathrm{O}$ emissions from the farmland (Yang, et al., 2017). Soil $\mathrm{N}_{2} \mathrm{O}$ emissions increased rapidly with the increase of nitrogen application, which has been observed and verified by many researchers (Zebarth, et al., 2012; Wang, et al., 2017). Excessive application of nitrogen fertilizer not only did not increase the yield but also tended to decrease the yield, which has also been reflected in other crops (Vanlauwe, et al., 2011; Hou, et al., 2012), and it was also consistent with the results of our experiments.

4.2 Study on the earlier sowing date based on the potato yield increase

In the sensitivity study of the DNDC model, a negative correlation was found between potato yield and average annual temperature, which indicated that lowering the temperature could increase the potato yield. In other words, potato could be sown at an earlier date. Taking 2017 as an example, potato production showed a significant decline only if the sowing date was advanced while the other conditions remained unchanged $(P<0.05)$, which was mainly because the earlier sowing date corresponded to lower precipitation. Precipitation had a limiting effect on potato growth. When the sowing date was $5,10,15,20,25$ and 30 days earlier, the precipitation during the growing period decreased by $18.2 \%, 32.3 \%, 39.4 \%, 46.9 \%$ and 50.9\%, respectively. However, in the DNDC model simulation, when the 2017 potato growth period precipitation $(211.7 \mathrm{~mm})$ was held constant (the rainfall days advanced according to the sowing date), the 
yield showed a parabolic trend $\left(y=-6.18 x^{2}+278.38 x+11024.0, R^{2}=0.84, P<0.01 ; \mathrm{x}\right.$ is the number of days in the earlier sowing date and $\mathrm{y}$ is the yield) with the earlier sowing dates. The number of days at the parabolic apex was 22.5 , meaning that the potato sowing date in 2017 should be 22.5 days earlier than April 28th (sowing on April 5th and April 6th) because the temperature conditions can meet the potato growth requirements. Moreover, the five day sliding average temperature on April 2nd was $10.54{ }^{\circ} \mathrm{C}$, and after April 2nd, it was higher than $10{ }^{\circ} \mathrm{C}$, while before April 2nd, it was lower than $10^{\circ} \mathrm{C}$. Therefore, April 2nd was the first day of 2017 when the five day sliding average temperature stabilized through $10{ }^{\circ} \mathrm{C}$, and April 5th and 6th were the 4th and 5th days.

The same phenomenon observed in 2018 and 2019, and the potato yield did not increase as expected and showed a downward trend by simply advancing the sowing date. Under constant rainfall (212.0 $\mathrm{mm}$ and $286.7 \mathrm{~mm}) \mathrm{during}$ the potato growth period in 2018 and 2019, the potato yield also showed a parabolic trend with the earlier sowing date (2018: $\left.y=-4.45 x^{2}+178.46 x+17802.12, R^{2}=0.86, P<0.01 ; 2019: \mathrm{y}=-6.30 \mathrm{x}^{2}+306.21 \mathrm{x}+15852.05, R^{2}=0.90, P<0.01\right)$. The number of days in 2018 and 2019 at the parabolic apex were 20.0 and 24.3. Therefore, the potato sowing date in 2018 should be 20.0 days earlier than April 30th (sowing on April 10th), and the potato sowing date in 2019 should be 20.0 days earlier than April 26th (sowing on April 2th). An obvious phenomenon was observed in which five day sliding average temperature was higher than $10{ }^{\circ} \mathrm{C}$ after April 8th in 2018 and April 1st in 2019 and lower than $10{ }^{\circ} \mathrm{C}$ after these dates. That is, April 8th in 2018 and April 1st in 2019 were the first days when the five day sliding average temperature stabilized through $10^{\circ} \mathrm{C}$, and April 10th and 2nd were the 3 rd and 2 nd days. et al., 2018). However, combining the yield simulation and actual production shows that the temperature is stabilized through sowing within 5 days after increasing to $10^{\circ} \mathrm{C}$ to achieve the purpose of increasing the yield under the premise of maintaining a normal water supply (such as by proper irrigation). Potato prefers cooler temperatures, and research on advancing potato sowing date is of positive significance to the improvement of potato yield under global warming (Stocker, et al., 2013).

\subsection{Effects of optimized nitrogen application and irrigation on $\mathrm{N}_{2} \mathrm{O}$ emissions and yield}

The sensitivity analysis showed that both the cumulative $\mathrm{N}_{2} \mathrm{O}$ emissions and yield were significantly affected during the potato growth period, and the controllable impact factors in actual production were the water supply and nitrogen application. In Section 4.2, it was mentioned that the earlier sowing date can increase the yield under the condition of ensuring the water supply. However, in actual production, the water supply does not rely solely on precipitation but is mainly achieved through irrigation. Therefore, this study took 2019 as an example and used the 


\begin{tabular}{cccc}
\hline $\begin{array}{c}\text { Irrigation volume per unit } \\
\text { area/mm }\end{array}$ & $\begin{array}{c}\text { Accumulated emission in growth } \\
\left.\text { period/(kgN/hm }{ }^{-2}\right)\end{array}$ & Yield $/ \mathrm{kg} \cdot \mathrm{hm}^{-2}$ & $\begin{array}{c}\text { Yield-scaled } \mathrm{N}_{2} \mathrm{O} \\
\text { intensity } /\left(\mathrm{gN} \cdot \mathrm{kg}^{-1}\right)\end{array}$ \\
\hline 0 & 0.415 & 15075.0 & 0.028 \\
5 & 0.447 & 16537.5 & 0.027 \\
10 & 0.476 & 17987.5 & 0.026 \\
15 & 0.523 & 19325.0 & 0.027 \\
20 & 0.581 & 19212.5 & 0.030 \\
25 & 0.624 & 19525.0 & 0.032 \\
30 & 0.670 & 19725.0 & 0.034 \\
35 & 0.721 & 19112.5 & 0.038 \\
40 & 0.758 & 19712.5 & 0.038 \\
45 & 0.809 & 19062.5 & 0.042 \\
50 & 0.851 & 19062.5 & 0.045 \\
\hline
\end{tabular}

and yields under the condition of optimized nitrogen application.

In this study, we used the DNDC model to simulate the change of potato yield with different nitrogen application rates. The yields all showed a parabolic trend with increases in the nitrogen application rate in 2017, 2018 and 2019 $(P<0.05)$. The nitrogen application rates at the parabolic apex were $91.1 \mathrm{~kg} \cdot \mathrm{hm}^{-2}, 98.7 \mathrm{~kg} \cdot \mathrm{hm}{ }^{-2} \mathrm{and} 93.6 \mathrm{~kg} \cdot \mathrm{hm}{ }^{-2}$ in 2017, 2018 and 2019, respectively. We took the average value of $94.5 \mathrm{~kg} \cdot \mathrm{hm}^{-2}$ as the nitrogen application rate based on the optimal nitrogen application for increasing yield and the conventional irrigation time of local farmers (approximately 45 days after sowing) to study the effects of these factors on the $\mathrm{N}_{2} \mathrm{O}$ emissions and yield.

Table $4 \mathrm{~N}_{2} \mathrm{O}$ emissions and yield under different irrigation volumes with the optimum nitrogen application level $\left(94.5 \mathrm{~kg} \cdot \mathrm{hm}^{-2}\right)$ for the potato field

The different irrigation amounts were set to simulate the changes of $\mathrm{N}_{2} \mathrm{O}$ emissions and yields (Table 4). Table 4 shows that when the irrigation amount was less than $15 \mathrm{~mm}$, the yield increased rapidly as the irrigation amount increased. Compared with $0 \mathrm{~mm}$ irrigation, the yield under 5, 10 and $15 \mathrm{~mm}$ irrigation increased by $9.7 \%, 19.3 \%$ and $28.2 \%$, respectively. Continuing to increase the irrigation amount would increase the yield slowly when the irrigation amount was more than $15 \mathrm{~mm}$. Compared with $15 \mathrm{~mm}$ irrigation, the yield of 20, 25, 30, 35, 40, 45 and $50 \mathrm{~mm}$ irrigation increased by $-0.6 \%, 1.0 \%, 2.1 \%,-1.1 \%, 2.0 \%,-1.4 \%$ and $-1.4 \%$, respectively. However, the cumulative $\mathrm{N}_{2} \mathrm{O}$ emissions still increased rapidly. Compared with $15 \mathrm{~mm}$ irrigation, the cumulative $\mathrm{N}_{2} \mathrm{O}$ emissions increased by $11.1 \%$, 

increase of irrigation amount when the irrigation amount was less than $15 \mathrm{~mm}$. Compared with $0 \mathrm{~mm}$ irrigation, the yield-scaled $\mathrm{N}_{2} \mathrm{O}$ intensity of 5, 10 and $15 \mathrm{~mm}$ irrigation increased by $-3.6 \%,-7.1 \%$ and $-3.6 \%$, respectively. Continuing to increase the irrigation amount would increase the yield-scaled $\mathrm{N}_{2} \mathrm{O}$ intensity rapidly. Compared with 15 mm irrigation, the yield-scaled $\mathrm{N}_{2} \mathrm{O}$ intensity of $20,25,30,35,40,45$ and $50 \mathrm{~mm}$ irrigation increased by $11.1 \%, 18.5 \%$, $25.9 \%, 40.7 \%, 40.7 \%, 55.6 \%$ and $66.7 \%$, respectively. Therefore, $15 \mathrm{~mm}$ irrigation was retained for the minimum yield-scaled $\mathrm{N}_{2} \mathrm{O}$ intensity while maintaining yield. The results indicate that a nitrogen application amount of 94.5 $\mathrm{kg} \cdot \mathrm{hm}^{-2}$ and an irrigation amount of $15 \mathrm{~mm}$ are the optimal values for reducing $\mathrm{N}_{2} \mathrm{O}$ emissions from potato fields under the premise of maintaining yield in the conventional farming systems used in the study area.

\subsection{Suggestions for DNDC model improvement}

There was a special phenomenon in this study by taking the N1 treatment in 2018 as an example (In Fig 5). The soil $\mathrm{N}_{2} \mathrm{O}$ emission of observing showed a small peak on July 7 and July 9, 2018, but the DNDC model did not simulate the emission peak(In Fig 6a). We found that there were precipitation of 7.3, 2.5 and $5.7 \mathrm{~mm}$ in the first three days of July 9, 2018, respectively. Therefore, we guessed that this phenomenon may be due to the model's not obvious response to low precipitation for several consecutive days.

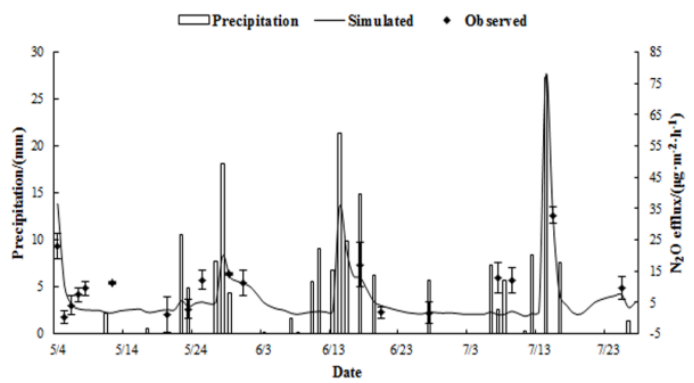

Fig. 5 The simulation and observing of $\mathrm{N}_{2} \mathrm{O}$ emission and precipitation in $\mathrm{N} 1$ treatment in 2018

Since farmland $\mathrm{N}_{2} \mathrm{O}$ emissions have great temporal and spatial variability, which is related to the three factors controlling the production of $\mathrm{N}_{2} \mathrm{O}$ (Eh in the soil (oxidation-reduction potential of the soil environment), Dissolved organic carbon (DOC), and available nitrogen (ammonium nitrogen, nitrate nitrogen)). Observations from around the world indicate that annual $\mathrm{N} 2 \mathrm{O}$ emissions in most places are integrated by a small number of emission peaks, and the DNDC model simulates the peak $\mathrm{N}_{2} \mathrm{O}$ emission based on this( $\left.\mathrm{Li}, 2016\right)$. Taking $\mathrm{N} 1$ nitrogen application level treatment as an example, DNDC model simulation showed that Eh was $764.3 \mathrm{mV}$ at $10 \mathrm{~cm}$ of soil on July 7 th, 2018. There was no obvious $\mathrm{N}_{2} \mathrm{O}$ emission peak in the simulated values. However, a rainfall on July 14 was $27.3 \mathrm{~mm}$, and Eh of the soil 10 cm was $421.4 \mathrm{mV}$ simulated by DNDC model. There was an obvious emission peak of $\mathrm{N}_{2} \mathrm{O}$. DNDC model is based on 
Nengst equation to calculate the simulated soil Eh. When there is rainfall, soil Eh decreases, and the extent of the decrease is related to the duration of rainfall. The longer the duration of rainfall, the more soil Eh decreases. Moreover, a certain threshold value is assigned to the Eh of the soil at the beginning of $\mathrm{N}_{2} \mathrm{O}$ emission (if the initial nitrate nitrogen concentration in the soil is $0.00357 \mathrm{~mol} \cdot \mathrm{L}^{-1}$, Eh is $460 \mathrm{mV}$ at the beginning of $\mathrm{N}_{2} \mathrm{O}$ emission). In the DNDC model, intensity of precipitation (Ip) is defined as a fixed value, that is, $0.5 \mathrm{~cm}$ per hour $\left(\mathrm{Ip}=0.5 \mathrm{~cm} \bullet \mathrm{h}^{-1}\right)$. Then, according to the whole precipitation $\left(\mathrm{Wp}, \mathrm{cm}^{\bullet} \mathrm{d}^{-1}\right)$ provid by meteorological data, the time of precipitation $(\mathrm{Tp}, \mathrm{h})$ is defined as: $\mathrm{Tp}=\mathrm{Wp} / \mathrm{Ip}(\mathrm{Li}, 2016)$.

However, the Ip is not a fixed value. So the Tp cannot be simply calculated with $\mathrm{Tp}=\mathrm{Wp} / \mathrm{Ip}$. The precipitation was $7.3 \mathrm{~mm}$ and $2.5 \mathrm{~mm}$ on July 6 and July 7 of 2018 , respectively. According to the Tp=Wp/Ip formula, the Tp of these two days was only $1.46 \mathrm{~h}$ and $0.5 \mathrm{~h}$ in the simulation of DNDC, respectively. However, in fact, the Tp on July 6 and 7 of 2018 was $3.5 \mathrm{~h}$ and $0.75 \mathrm{~h}$, respectively. The actual $\mathrm{Tp}$ was converted into $\mathrm{Wp}$ by $\mathrm{Tp}=\mathrm{Wp} / \mathrm{Ip}$, and input into the DNDC model. The DNDC model was able to accurately simulate the $\mathrm{N}_{2} \mathrm{O}$ emission peak on 6 July 2018 (In Fig 6b). This practice of converting the actual $\mathrm{Tp}$ into $\mathrm{Wp}$ input into the model according to the formula applied in the model has increased the
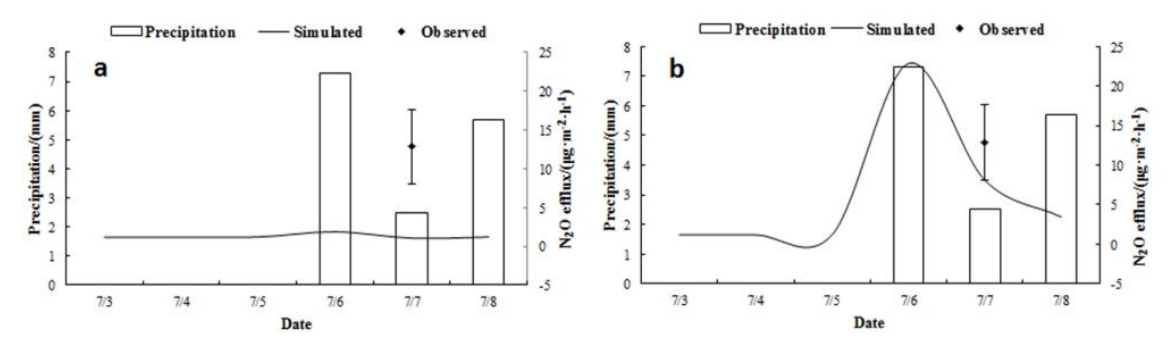
actual $\mathrm{Wp}$, but this attempt had achieved more accurate simulation results. It shows that the optional input items of the input module of daily intensity of precipitation and time of precipitation should be considered in the DNDC model. This is to accurately simulate the $\mathrm{N}_{2} \mathrm{O}$ emission characteristics of low and longtime of precipitation.

Fig. 6 The simulation of $\mathrm{N}_{2} \mathrm{O}$ emission before and after improvement and observing of $\mathrm{N}_{2} \mathrm{O}$ emission and precipitation in N1 treatment in 2018

\section{Conclusions}

Based on a 3-year experiment in a potato field, the effects of multiple factors on $\mathrm{N}_{2} \mathrm{O}$ emissions and yield have been discussed in this paper using the DNDC model, which had a good simulation effect on $\mathrm{N}_{2} \mathrm{O}$ emission and yield in the potato field. The simulation effect of the DNDC model was better for $\mathrm{N}_{2} \mathrm{O}$ emissions. The simulation of the $\mathrm{N}_{2} \mathrm{O}$ emission effect in the low nitrogen treatment was better than that of the high nitrogen treatment. The model efficiency indexes EFs were from $0.45 \sim 0.88$ for $\mathrm{N}_{2} \mathrm{O}$ emissions $0.91,0.85$ and 0.85 for yield from 2017 2019. The annual precipitation, soil organic carbon and soil bulk density had the most significant influence on the accumulated $\mathrm{N}_{2} \mathrm{O}$ 
emissions during the growth period of potato, and the sensitivity index values were 1.894, 1.052 and 1.129, respectively. Positive correlations were observed between those factors and emissions. The annual precipitation, annual average temperature and $\mathrm{CO}_{2}$ mass concentration had the most significant influence on yield, and the sensitivity index values were $0.723,-0.508$ and 1.295 , respectively. Positive correlations were observed between the $\mathrm{CO}_{2}$ mass concentration and annual precipitation and the yield while a negative correlation was observed between the annual average temperature and the yield. By combining the DNDC simulation and actual production, the temperature is stabilized by sowing potato crops within 5 days after reaching $10{ }^{\circ} \mathrm{C}$ to achieve increased yield while maintaining a normal water supply. The nitrogen application amount of $94.5 \mathrm{~kg} \cdot \mathrm{hm}^{-2}$ and the irrigation amount of $15 \mathrm{~mm}$ represented the optimal values for reducing $\mathrm{N}_{2} \mathrm{O}$ emissions from the potato field under the premise of maintaining yield in the conventional farming systems of the study area.

Acknowledgements This research was funded by the National Key Research and Development Program of China (2019YFD1002204), National Natural Science Foundation of China (32001409), Science and technology research project of Liaoning Provincial Department of Education (LSNQN201711). The authors would like to extend their thanks and appreciation to the staff at the College of Agronomy, Shenyang Agricultural University for assisting in all experiments.

Author Contributions: Conceptualization, L.W. and X.G.; methodology, L.W. and M.J.; software, K.Z. and K.G.; validation, L.W. and L.L.; formal analysis, L.W. K.Z. and K.G.; investigation, L.W., K.Z. K.G. T.Z. and X.Y.; resources, L.W. and X.G.; data curation, L.W.; writing—original draft preparation, L.W.; writing—review and editing, L.W.; supervision, X.G.; project administration, X.G. All authors have read and agreed to the published version of the manuscript.

Conflict of interest: The authors declare that they have no conflict of interest.

Ethics approval: Not applicable.

Consent to participate:I am free to contact any of the people involved in the research to seek further clarification and information.

Consent for publication: Not applicable.

Availability of data and materials: The datasets used and/or analyzed during the current study are available from the corresponding author on reasonable request.

\section{References}

Agbede, T. (2010) Tillage and fertilizer effects on some soil properties, leaf nutrient concentrations, growth and sweet potato yield on an Alfisol in southwestern Nigeria. Soil Till Res, 110 (1), 25-32. https://doi.org/10.1016/j.still.2010. 
06.003

Agehara, S.; Warncke, D.(2005) Soil moisture and temperature effects on nitrogen release from organic nitrogen sources. Soil Sci Soc Am J, 69 (6), 1844-1855. https://doi.org/10.2136/sssaj2004.0361

Balaine N, Clough T J , Beare M H, Thomas S M, Meenken E D. (2016) Soil gas diffusivity controls NO and N Emissions and their ratio. Soil Sci Soc Am J, 80(3):529. https://doi.org/10.2136/sssaj2015.09.0350

Banerjee, S.; Helgason, B.; Wang, L.; Winsley, T.; Ferrari, B. C.; Siciliano, S. D.(2016) Legacy effects of soil moisture on microbial community structure and $\mathrm{N}_{2} \mathrm{O}$ emissions. Soil Biol. Biochem., 95, 40-50. https://doi.org/ 10.1016/j.soilbio.2015.12.004

Barton, L.; Kiese, R.; Gatter, D.; BUTTERBACH-BAHL, K.; Buck, R.; Hinz, C.; Murphy, D. V.( 2008) Nitrous oxide emissions from a cropped soil in a semi-arid climate. Glob. Change Biol., 14 (1), 177-192. https://doi.org/10.1111/j.1365-2486.2007.01474.x

Burton, D.; Zebarth, B.; Gillam, K.; MacLeod, J. (2008) Effect of split application of fertilizer nitrogen on $\mathrm{N}_{2} \mathrm{O}$ emissions from potatoes. Can J Soil Sci, 88 (2), 229-239. https://doi.org/10.4141/CJSS06007

Cavigelli, M.; Robertson, G. (2001) Role of denitrifier diversity in rates of nitrous oxide consumption in a terrestrial ecosystem. Soil Biol. Biochem., 33 (3), 297-310. https://doi.org/10.1016/S0038-0717(00)00141-3

Čuhel, J.; Šimek, M.; Laughlin, R. J.; Bru, D.; Chèneby, D.; Watson, C. J.; Philippot, L. (2010) Insights into the effect of soil $\mathrm{pH}$ on $\mathrm{N}_{2} \mathrm{O}$ and $\mathrm{N}_{2}$ emissions and denitrifier community size and activity. Appl. Environ. Microbiol., 76 (6), 1870-1878. https://doi.org/10.1128/AEM.02484-09

Cui, G., Wang, J. (2019) Improving the DNDC biogeochemistry model to simulate soil temperature and emissions of nitrous oxide and carbon dioxide in cold regions. Sci. Total Environ.,687, 61-70. https://doi.org/10.1016/j.scitotenv. 2019.06.054

Deng, J.; Zhu, B.; Zhou, Z.; Zheng, X.; Li, C.; Wang, T.; Tang, J. (2011) Modeling nitrogen loadings from agricultural soils in southwest China with modified DNDC. J. Geophys. Res.-Biogeosci., 116 (G2). https://doi.org/ 10.1029/2010JG001609

Deng, M., Hou, M., Zhang, Q., Bellingrath-kimura, S. D. (2020) Critical livestock densities and manure management for the typical paddy rice and corn cropping systems in an intensive livestock watershed, Japan. Agr Syst, 177. https://doi.org/10.1016/j.agsy.2019.102722

Dijkstra, F. A.; Prior, S. A.; Runion, G. B.; Torbert, H. A.; Tian, H.; Lu, C.; Venterea, R. T. (2012) Effects of elevated carbon dioxide and increased temperature on methane and nitrous oxide fluxes: evidence from field experiments. Front. Ecol. Environ., 10 (10), 520-527. https://doi.org/10.2307/41811865

Elmi, A.; Mehdi, B.; Chandra, M.; Dam, R.; Smith, D. (2009) Long-term effect of conventional and no-tillage production systems on nitrous oxide fluxes from corn (Zea mays L.) field in Southwestern Quebec. Am. J. Environ. Sci., 5 (3), 238-246. https://doi.org/10.3844/ajessp.2009.238.246

Giltrap, D. L.; Li, C.; Saggar, S. (2010) DNDC: A process-based model of greenhouse gas fluxes from agricultural soils. Agric. Ecosyst. Environ., 136 (3-4), 292-300. https://doi.org/10.1016/j.agee.2009.06.014

Han, J.; Jia, Z.; Wu, W.; Li, C.; Han, Q.; Zhang, J. (2014) Modeling impacts of film mulching on rainfed crop yield in Northern China with DNDC. Field Crop Res, 155, 202-212. https://doi.org/10.1016/j.fcr.2013.09.004

Hou, P.; Gao, Q.; Xie, R.; Li, S.; Meng, Q.; Kirkby, E. A.; Römheld, V.; Müller, T.; Zhang, F.; Cui, Z. (2012) Grain yields in relation to $\mathrm{N}$ requirement: Optimizing nitrogen management for spring maize grown in China. Field Crop Res, 129, 1-6. https://doi.org/10.1016/j.fcr.2012.01.006

Hu, M.; Chen, D.; Dahlgren, R. A. (2016) Modeling nitrous oxide emission from rivers: a global assessment. Glob. Change Biol., 22 (11), 3566-3582. https://doi.org/10.1111/gcb.13351

Kallenbach, C. M.; Rolston, D. E.; Horwath, W. R. (2010) Cover cropping affects soil $\mathrm{N}_{2} \mathrm{O}$ and $\mathrm{CO}_{2}$ emissions differently depending on type of irrigation. Agr Ecosyst Environ, 137 (3-4), 251-260. https://doi.org/10.1016/ 
j.agee.2010.02.010

Khalil, M. I., Fornara, D. A., Osborne, B. (2020) Simulation and validation of long-term changes in soil organic carbon under permanent grassland using the DNDC model. Geoderma, 361. https://doi.org/10.1016/j.geoderma.2019. 114014

Kou, T.; Zhu, J.; Xie, Z.; Liu, G.; Zeng, Q. (2008) Effect of elevated atmospheric $\mathrm{CO}_{2}$ concentration and level of nitrogen fertilizer on root respiration and biomass of winter wheat. Chin. J. Plant Ecol, 32, 922-931. https://doi.org/10.3724/SP.J.1005.2008.01083

Lam, S. K.; Chen, D.; Norton, R.; Armstrong, R.; Mosier, A. R. (2012) Nitrogen dynamics in grain crop and legume pasture systems under elevated atmospheric carbon dioxide concentration: A meta-analysis. Glob. Change Biol., 18 (9), 2853-2859. https://doi.org/10.1111/j.1365-2486.2012.02758.x

Lan, T., Suter, H., Liu, R., Yuan, S., Chen, D. (2018) Effects of nitrification inhibitors on gross N nitrification rate, ammonia oxidizers, and $\mathrm{N}_{2} \mathrm{O}$ production under different temperatures in two pasture soils. Environ. Sci. Pollut. Res. 25, 28344 - 28354. https://doi.org/10.1007/s11356-018-2873-6

Li, C.; Frolking, S.; Frolking, T. A. (1992) A model of nitrous oxide evolution from soil driven by rainfall events: 1. Model structure and sensitivity. J. Geophys. Res.-Atmos., 97 (D9), 9759-9776. https://doi.org/10.1029/92JD00510

Li, C.; Salas, W.; Zhang, R.; Krauter, C.; Rotz, A.; Mitloehner, F. (2012) Manure-DNDC: a biogeochemical process model for quantifying greenhouse gas and ammonia emissions from livestock manure systems. $\mathrm{Nutr} C \mathrm{Cl}$ Agroecosys, 93 (2), 163-200. https://doi.org/10.1007/s10705-012-9507-z

LI C., (2016) Biogeochemistry: scientific fundamentals and modeling approach[M]. Beijing: Tsing Hua University Press.

Li, H.; Qiu, J.; Wang, L.; Tang, H.; Li, C.; Van Ranst, E. (2010) Modelling impacts of alternative farming management practices on greenhouse gas emissions from a winter wheat-maize rotation system in China. Agric. Ecosyst. Environ., 135 (1-2), 24-33. https://doi.org/10.1016/j.agee.2009.08.003

Li, Q.; Li, H.; Zhang, L.; Zhang, S.; Chen, Y. (2018) Mulching improves yield and water-use efficiency of potato cropping in China: A meta-analysis. Field Crop Res, 221, 50-60. https://doi.org/10.1016/j.fcr.2018.02.017

Logsdon, S. D.; Karlen, D. L. (2004) Bulk density as a soil quality indicator during conversion to no-tillage. Soil Till Res, 78 (2), 143-149. https://doi.org/10.1016/j.still.2004.02.003

Luo, G.; Kiese, R.; Wolf, B.; Butterbach-Bahl, K. (2013) Effects of soil temperature and moisture on methane uptakes and nitrous oxide emissions across three different ecosystem types. Biogeosciences, 10 (1), 3205-3219. https://doi.org/10.5194/bg-10-3205-2013

Magill, A. H.; $\quad$ Aber, J. D.; $\quad$ Berntson, G. M.; McDowell, W. H.; $\quad$ Nadelhoffer, K. J.; Melillo, J. M.; Steudler, P. (2000) Long-term nitrogen additions and nitrogen saturation in two temperate forests. Ecosystems, 3 (3), 238 -253. https://doi.org/10.1007/s100210000023

Mapanda F , Wuta M , Nyamangara J , Rees R M. (2011) Effects of organic and mineral fertilizer nitrogen on greenhouse gas emissions and plant-captured carbon under maize cropping in Zimbabwe. Plant Soil, 343(1-2):67-81. https://doi.org/10.1007/s11104-011-0753-7

Matson, P.; Lohse, K. A.; Hall, S. J. (2002) The globalization of nitrogen deposition: consequences for terrestrial ecosystems. Ambio, 113-119. https://doi.org/10.1639/0044-7447(2002)031[0113:TGONDC]2.0.CO;2

McGrath, J. M.; Lobell, D. B. (2013) Regional disparities in the $\mathrm{CO}_{2}$ fertilization effect and implications for crop yields. Environ. Res. Lett., 8 (1), 014054. https://doi.org/10.1088/1748-9326/8/1/014054

Pulatov, B.; Linderson, M.-L.; Hall, K.; Jönsson, A. M. (2015) Modeling climate change impact on potato crop phenology, and risk of frost damage and heat stress in northern Europe. Agr Forest Meteorol, 214, $281-292$. https://doi.org/10.1016/j.agrformet.2015.08.266

Raymundo, R.; Asseng, S.; Prassad, R.; Kleinwechter, U.; Concha, J.; Condori, B.; Bowen, W.; Wolf, J.; Olesen, J. E.; 
Dong, Q. (2017) Performance of the SUBSTOR-potato model across contrasting growing conditions. Field Crop Res, 202, 57-76. https://doi.org/10.1016/j.fcr.2016.04.012

Reyes-Cabrera, J.; Zotarelli, L.; Dukes, M. D.; Rowland, D. L.; Sargent, S. A. (2016) Soil moisture distribution under drip irrigation and seepage for potato production. Agr Water Manage, 169, 183-192. https://doi.org/ 10.1016/ j.agwat.2016.03.001

Robertson, G. P. 2004. Abatement of nitrous oxide, methane, and the other non- $\mathrm{CO}_{2}$ greenhouse gases: The need for a systems approach. Pages 493-506 in C. B. Field and M. R. Raupach, eds. The Global Carbon Cycle. Island Press, Washington, DC, USA.

Sanchez-Martín, L.; Meijide, A.; Garcia-Torres, L.; Vallejo, A. (2010) Combination of drip irrigation and organic fertilizer for mitigating emissions of nitrogen oxides in semiarid climate. Agric. Ecosyst. Environ., 137 (1-2), 99-107. https://doi.org/10.1016/j.agee.2010.01.006

Shah, S. H., Li, Y., Wang, J., Collins, A. L. (2020) Optimizing farmyard manure and cattle slurry applications for intensively managed grasslands based on UK-DNDC model simulations. Sci. Total Environ., 714. https://doi.org/ 10.1016/j.scitotenv.2020.136672

Shang, Q.; Yang, X.; Gao, C.; Wu, P.; Liu, J.; Xu, Y.; Shen, Q.; Zou, J.; Guo, S. (2011) Net annual global warming potential and greenhouse gas intensity in Chinese double rice-cropping systems: a 3-year field measurement in long-term fertilizer experiments. Glob. Change Biol., 17 (6), 2196-2210. https://doi.org/ 10.1111/j.1365-2486. 2010.02374.x

Stocker, T. F.; Qin, D.; Plattner, G.-K.; Tignor, M.; Allen, S. K.; Boschung, J.; Nauels, A.; Xia, Y.; Bex, V.; Midgley, P. M. (2013) Climate change 2013: The physical science basis. Contribution of working group I to the fifth assessment report of the intergovernmental panel on climate change, 1535. https://doi.org/10.1007/BF00524943

Turner, P. A.; Griffis, T. J.; Lee, X.; Baker, J. M.; Venterea, R. T.; Wood, J. D. (2015) Indirect nitrous oxide emissions from streams within the US Corn Belt scale with stream order. Proc. Natl Acad. Sci. USA, 112 (32), 9839-9843. https://doi.org/10.1073/pnas.1503598112

Vanlauwe, B.; Kihara, J.; Chivenge, P.; Pypers, P.; Coe, R.; Six, J. (2011) Agronomic use efficiency of N fertilizer in maize-based systems in sub-Saharan Africa within the context of integrated soil fertility management. Plant Soil, 339 (1-2), 35-50. https://doi.org/10.1007/s11104-010-0462-7

Walker, S.; Mitchell, J.; Hirschi, M.; Johnsen, K. (2000) Sensitivity analysis of the root zone water quality model. $T$ Asae, 43 (4), 841. https://doi.org/10.13031/2013.2978

Wang, L.; Wang, C.; Pan, Z.; Xu, H.; Gao, L.; Zhao, P.; Dong, Z.; Zhang, J.; Cui, G.; Wang, S.; Han, G.; Zhao, H. (2017) $\mathrm{N}_{2} \mathrm{O}$ emission characteristics and its affecting factors in rain-fed potato fields in Wuchuan County, China. Int $J$ Biometeorol, 61 (5), 911-919. https://doi.org/10.1007/s00484-016-1271-3

Xu, X.; Liu, X.; Li, Y.; Ran, Y.; Liu, Y.; Zhang, Q.; Li, Z.; He, Y.; Xu, J.; Di, H. (2017) High temperatures inhibited the growth of soil bacteria and archaea but not that of fungi and altered nitrous oxide production mechanisms from different nitrogen sources in an acidic soil. Soil Biol. Biochem., 107, 168-179. https://doi.org/ 10.1016/j.soilbio. 2017.01 .003

Yang, J.; Yang, J.; Liu, S.; Hoogenboom, G. (2014) An evaluation of the statistical methods for testing the performance of crop models with observed data. Agr Syst, 127, 81-89. https://doi.org/10.1016/j.agsy.2014.01.008

Yang, Y., Meng, T., Qian, X., Zhang, J., Cai, Z. (2017) Evidence for nitrification ability controlling nitrogen use efficiency and N losses via denitrification in paddy soils. Biol. Fertil.Soils 53, 349-356. https://doi.org/ 10.1007/ s00374-017-1185-1

Zebarth, B. J.; Snowdon, E.; Burton, D. L.; Goyer, C.; Dowbenko, R. (2012) Controlled release fertilizer product effects on potato crop response and nitrous oxide emissions under rain-fed production on a medium-textured soil. Can $J$ Soil Sci, 92 (5), 759-769. https://doi.org/10.4141/cjss2012-008 
544

545

546

547

548

Zhang, X.; Hu, D. (2014) Overcoming successive bottlenecks: The evolution of a potato cluster in China. World Dev., 63, 102-112. https://doi.org/10.1016/j.worlddev.2013.10.003

Zhang, Y. and Niu, H., 2016. The development of the DNDC plant growth sub-model and the application of DNDC in agriculture: a review. Agric. Ecosyst. Environ., 230, 271-282. https://doi.org/10.1016/j.agee.2016.06.017 